\title{
Foucault's Paradox: From Inversionary Discourse to Hegemonic Power in "Mao's Republic"
}

\author{
DAVID E. APTER
}

\section{The Redemptive Fallacy}

"Who now reads Foucault"? For that matter who now reads Marx, Sartre, Levi-Strauss, deconstructivists and even the "post" postmodernists? Analytical worlds change intellectual couturiers almost as quickly as the world of fashion changes designers (despite, or perhaps because of the lockjaw language towards which they incline). Similarly with powerful political leaders. Suddenly, no matter how much power they exercised, their world becomes quaint. How difficult it is to recuperate the significance of a Lenin or a Mao Zedong both of whom literally defined the terms of politics and who today seem entirely unreal, cardboard figures in the large display of history, their moral moments irretrievable.

To many today we are, instead, at the end of history, of ideology. These have been killed by a market whose universal rationality defines the terms of a distributional equity. So much for the moral Aufheben, the logic of the revolutionary disjunction, the last becoming first. Gone is a certain certainty about the future especially of the kind in which knowledge is not just knowledge and power is not just power and both derive meaning from their emancipatory objects.

It is in terms of political meanings rather than distributional allocations that we need to see these two figures, Foucault and Mao Zedong. Each in his one way marks the end of an era. For theirs' was a world in which politics could never be just politics, neither for Foucault, the activist-scholar, nor Mao, the archetype of the revolutionary cosmocrat. Both believed in a politics of the moral moment, the radical disjunctive transformation. Today the Foucault "myth" 
has been exploded leaving behind a sense that he got what he deserved - a tragedy yes, but of his own making. So too, whatever was left of the Mao mystique was finished off in Tiananmen Square in June 1989.

But why the comparison? Whatever else one can say about Mao he had a huge impact on history. No one would ever claim that for Foucault. Their connection becomes relevant only in this one respect. They were among the last significant inversionaries - believers in the necessity of permanent revolution.

Of course, this judgement may be a bit premature. The Marxist corpus gets periodically revived. So does critical and radical disjunctive theory. So much does each generation recuperate those the previous one has consigned to the dustbin that one can speak of a "myth of the eternal return" in social analysis, as well as in politics. If so, might it not be the case that despite the current wave of disillusion with totalizing solutions, the idea of an inversionary solution embodied in a surrogate role or class, or other agent as alter, (thief, transvestite, if not proletarian or peasant), will come back, and if not in political then religious or fundamentalist guise? Indeed, who among the "modernists" would have expected the revival of all those "parochialisms" which seemed to characterize 19th century politics more than 20th. And who can predict what pariah caste or class or agent will be chosen next to save us from ourselves. What is interesting about Foucault and Mao is that in their differing ways they represent punctuation marks, the one in intellectual history, the other in history itself. Both sought the critical "break" in the seamless web of a normalcy they regarded as hegemonic. For Mao the method was dialectical, the identification of contradictions, manifested as crises and expressed in class conflict. For Foucault it was Hegel's master and slave all over again, in the form of the state and its victims.

Both were obsessed by "les vulnerables", the negatived class or other who were then credited with the uniquely transformative power of revelatory insight, a higher knowledge than that possessed by civil society and the state as constituted. Indeed, from Bakunin to Marx to Mao this transformative vision, embodied in the wisdom of a revolutionary class, lumpens for the first, proletarians for the second, and peasants for the third and been transmitted as an inheritance from one radical generation, to more or less come to an end in the present. Yet in each case it was the claim, rather than the belief 
itself, which was important. For their truth claims were much more significant as history than the truth value of their ideas.

Foucault emphasized less the monopoly of coercive power by the state in its more conventional sense than the coercive impact of the professionalization of knowledge. Bureaucratized, institutionalized, and distributed through the structures of civil society, the result was a kind of authority to which he was simply allergic. For him, the state as an embodiment of knowledge was punitive, hegemonic, and morally reprehensible. But for a good part of his life he too believed in the redeeming power of those marginalized by science and knowledge, the criminology that authorizes prisons and validates the sequestering of the transgressor of the law, the medicine that defines the sick, the psychiatry of the mentally deranged. ${ }^{1}$

Such views have a long pedigree. It includes early and late radical evangelical Christianity, anarchism, Hegelianism, early and late Marxism and many other permutations up to and including Mao and Foucault. Its underlying problem is less the critique than the solution. Civil societies and states do retain the unfortunate habit of condemning those deemed too "different". Indeed, the state takes the position of ego to "alters" and is not at all likely to take kindly to any role or group which represents itself, by virtue of being "last" as candidate for becoming "first" especially when the claim is made that only in the more general emancipation is there profit of all. ${ }^{2}$ So, if Foucault is dead, (and Marx and Mao), and his (and their) books ready for the embalming, their paradoxes go marching on. People may stop accepting any particular version of what will be called here the redemptive fallacy but this will not stop them from inventing new forms. Among the sometimes consequences of this belief in the redemptive fallacy is political violence. And it is here that Foucault parts company with Mao. For with Foucault the theme is sacrifice. The sacrifice of the inverted other has consequence in the moral fine tuning of society. For a Mao, as with Marx, what counts is class/civil war, i.e. the revolutionary disjunctive break.

Despite these differences, and they are fundamental, the continuity between a Foucault and a Mao is this. For both there is a negative pole to be transcended and an overcoming project to be defined. Their common point of departure is those most penalized and vulnerable who, because of their condition, are able to refract and reveal the hegemony of the productive classes. But in the end both came to 
question whether such refractory and revelatory power would in any way redress the condition of state power. For no group or class could gain a more secure lock on a more equitable future, in the end there would only be permanent struggle, permanent revolution. It is here where Foucault and Mao share common group. Struggle becomes the solution, the thing in itself.

Foucault's was always the more explicitly moral theory. From Marx to Mao the effort was to make history its own moralizer. Such moralities that they professed were in any case cast in the form of a persuasively dealienating political economy underlying a projective historicism.

\section{Marginality as the Negative Pole}

This suggested that the point of departure for any inversionary theory can be called its negative pole and that political struggle substitutes for final outcomes. Millennialism is dead - long live the struggle to achieve it. Those clustered at that pole, whether roles or classes, and share a common condition of marginality will be the ones engaged in permanent struggle, and the participants will change while the phenomenon remains the same. So for a Mao, the ground zero for his inversionary discourse was the marginalization of the peasantry through the loss of its patrimony to landlords, and the marginalization of the country due to imperialism, the two being part of the same process. Out of this "history" he produced narratives of loss and projections of redemptive gain, the displaced condition leading to the overcoming project. In the end it was that project which failed him.

What is perhaps more significant about both Foucault and Mao is not that the marginalized represent those separated from the rest of society but that the separation is contained within the categories of the dominant discourse. While the Marxist tradition represents them in class surrogate terms (as with Marx's proletariat or Mao's peasants), the same reasoning can be extended to other categorical groups, racially, ethnically, religiously, or linguistically defined. And, to use the terms of reference of Sartre and Foucault, negativized roles, (thief, murderer, madman, homosexual).

Their importance is not their marginality per se, but the position they are awarded in politics, i.e. as markers of the permissible outer 
social and cognitive boundaries of state and society. That is, marginality represents the farthest social distance from the center in moral, economic, and racial, ethnic and other terms.

Marginality thus is a status condition converted into an interpretive one. Around it are erected symbolic boundaries difficult to transcend or permeate. Castelike, a form of pariahdom, they are assigned a place by the dominant discourse which, in political terms, can be described as invisible. So what are in part symbolic boundaries become reinforced by physical ones, lines drawn in space, neighborhood, ghetto, and in the extreme case, the prison and the asylum.

Reading Foucault and Mao, two main types of marginality emerge. For Mao the most important is functional. Functional marginality is determined by the value of the contribution made to the social product. For Mao, and Marxists generally, this is made by a class, but it can extend to any group, role, or individual. In these terms rejected in Marx but not in Mao (who was closer to the anarchists in taking this position), are those who make negative contributions, "lumpens" who take out more than they put in, and under conditions described by Arendt as "abject poverty" of a kind leading to "acute misery" in which the "absolute dictate of their bodies" generates a logic of necessity. In our terms such marginality can be called functional superfluousness.

The other, which one finds in Foucault, might be called discourse marginality. ${ }^{3}$ It takes the form of prejudice, manifested in discrimination measured in that social distancing on which hierarchy as the embodiment of the dominant discourse, itself depends. It may take very explicit forms, as with whites and blacks in the U.S. or South Africa, Nazism and the Jews. It may be discursively disguised by professed principles of the dominant discourse. ${ }^{4}$

Functional and discourse marginality tend to go together. It is the functionally superfluous who become the pariahs and outcasts of society. For Mao, the marginalization of the peasants coincides with the marginalization of China, its decentering, bringing down on it (among other things) "Yellow Peril" racism (most explicitly on the part of the United States and France) and on the part of the Japanese, more ambiguously to be sure, cultural and "racial" contempt. 


\section{Inversionary Discourse Theory}

Seen in this light, marginality is first a structural condition and second an interpretative opportunity. The inversionary task is to transform marginality into functionality by altering the discourse itself. Indeed, what makes Mao interesting for our purposes is his recognition that it was the discourse which first had to be changed, and under circumstances of violence. But not any violence. The acts of violence had to be meaningful in terms of the discourse, i.e. to form into a social text. The object was to create a radical discourse community and not a political party with a radical ideology. Nothing else would do but a totalized framework for interpretive action. $\mathrm{He}$ went from events, to social text, to moral moment. Mao's moral moment was Yan'an. It was there that the passive voice became active. ${ }^{5}$ So much so that Yan'an remains a model type of what can be called the redemptive fallacy.

The moral moment lasted only a short time but it had repercussions outside of China as well as inside. It affected the so-called soixante-huitieme generation in France. ${ }^{6}$ (And the crowds of chanting students who waved the little red book on university campuses all over the world.) It remains today embodied in the doctrinal megalomania of the Sendero Luminoso in Peru. Mao achieved what Foucault hoped for and did not, i.e. the generation of a moral moment through the power of an inversionary discourse.

Success or not such events suggest the value of discourse theory as a way of interpreting political violence generally and revolution in particular. ${ }^{7}$ It draws attention to how boundaries in the mind seek to realize themselves on the ground. For in this sense discourses define or redefine jurisdictions, locate "chosen" classes, or categories (the political class versus the powerless) and, when inversionary, establish a ground zero for an overcoming project directed against society and state (Foucault's "carceral city").

Of course the content of such discourses can vary greatly. More abstractly they connect a past which is a lesson from history, to a future which is learned from the lesson. It takes the form of a projective logic - a logic not based directly on events but their narrativized form. Or, to put it another way, it locates events which become mythic in the telling. Contained in such myths are self defining and inscripted parables of loss, and both at individual and collective levels. Concretizing loss makes it possible to formulate concrete and 
programmatic strategies which give immediate substance to the larger overcoming project. The result is hermetic and circular.

How do narratives form which give rise to logic and theory? By what techniques is it possible to make the conversion from myth to logic and back again? How are confrontational events of the past made compelling as part of the present? What stories are selected to that events can be "read" as social texts? How do social texts become real ones, to be used for instruction? Narration gives events structure. Texts give the structure logic. Together, with millennial outcomes they establish higher truths - a teleology. They make revolutionary transcendence not outrageous but reasonable.

The term discourse then refers to the totality of discursive practices shared by members of the movement as a collectivity. ${ }^{9}$ More generally, as outlined above, the logic and the myth contains two component dimensions. One is structural, revealing the semiotic or signifying aspects of political discourse. ${ }^{10}$ This includes codes, rituals and other symbolic endowments. ${ }^{11}$ These, a context of self righteous anger, gives discourse its power. ${ }^{12}$ A second is phenomenological, in Ricoeurian terms - a phenomenology of overcoming. Both aspects are extremely well illustrated in Yan'an. There one found a double overcoming. Self overcoming its negative circumstances. Collectivity transforming the conditions of marginality. Combined in retrievals and projections, individuals came to see themselves as the chosen instruments for a disjunctive and overturning process.

We can see this in terms of Yan'an which embodied its own "retrievals". These contained echoes of the Jacobin phase of the French revolution, the Communes of 1848 and 1870, the Bolshevik revolution in Russia. Yan'an thus expropriated a whole revolutionary repertoire and iconography as well as an evolutionary logic of the texts. ${ }^{13}$

The mimetic progenitor was the Russian revolution and particularly Leninism. ${ }^{14}$ For Lenin by providing the master narrative of the revolution became the first true radical revolutionary cosmocrat. He succeeded in endowing virtually every act with a larger significance. $\mathrm{He}$ appeared, moreover, to elevate a politics of class interest (economism) into a politics of principle (the dialectic), which, conveniently enough permitted all matter of practical and instrumental actions to be justified. Confrontation could give way to cooperation (the United Front), cleavages exploited and coalitions eschewed de- 
pending not only on the appearance of circumstance but the logic of situation.

With such a logic principle is elevated over interests. Conflict appears as the inevitable result of larger material contradictions deriving from social and economic processes. The same logic could be applied to all the arenas of political action. Of course circumstances are constantly changing. The grounding of violence shifts sometimes in more subterranean ways and sometimes more superficially, but there is little doubt that as a phenomenon political violence is becoming more rather than less widespread. ${ }^{15}$

Today's emphasis is less on the kind of revolutionary violence represented in Yan'an, (and which has undergirded much of the political violence of this century) and more on ethnic, religious, linguistic, racial, and other forms. In this respect ideological millennialism has declined in favor of more primordial affiliations. ${ }^{16}$ Instead of a class with radical chains one now finds a marginalized and negativized ethnicity, forms of "neo-tribalism", religious fundamentalism, etc., but these also involve discourse and each of these movements form into discourse communities. ${ }^{17}$ These, the moral properties of the sacrally endowed, as with the Hezbollah in Lebanon or other fundamentalist and revivalism groups have their own sources of mobilizable power. ${ }^{18}$ So, for all the differences such shifts may represent, there is considerable common ground between the primordial and the more ideologically formed movements like Baader-Meinhof, Red Brigades, or the Tamil Tigers in Sri Lanka. All represent different expressions of discourse communities. ${ }^{19}$ In short one can apply discourse theory of the sort we have in mind in all those circumstances where the inversionary fallacy prevails. This suggests that Yan'an continues to offer abundant materials of relevance to more contemporary events.

One question which discourse theory poses is whether or not those most involved in its invention believe in the truths they claim to articulate. Does Guzman, the self proclaimed Maoist leader of Sendero Luminoso (now languishing in jail), really believe what he has declaimed, i.e. that the inversionary discourse he has developed will incorporate the world revolutionary mission that has been abdicated by all other communist parties and erstwhile communist countries? On the face of it it is absurd. Yet his followers continue to pore over his texts as if they were missals, intoning the logic that 
supports a structure of mutual confidences and by so doing bolstering their convictions, their belief in outcomes. This suggests that there is something special in the connection between discourse and violence when the symbolism of the latter illuminates from within the incantory power of the word.

We want to explore further the connection between this incantory pleasure and the violent act. For it goes well beyond the radical structuralism which located systemic contradictions in capitalism or other political and economic systems. Indeed, from this point of view, systemic revolutionary theory becomes the least interesting kind, except insofar as it offers to the discourse some sense of underlying truth, and in the form of revealed history converts myths into realities.

Once discourse connects with actual violence, the two reinforce one another. The result is not permanent revolution perhaps but enduring violence. For in this sense political violence creates its own objects, and the discourse so intertwined with it becomes part of its power. Objects and principles get separated from the original triggering events to establish their own momentum. It is then that discourse becomes mobilized, i.e. when events becoming mythically and logically orchestrated to provide both an immediate rationale and a self establishing boundary; an affiliational requirement, and a set of obligations. One might say that once political violence passes a certain symbolic threshold and these factors become set, it is virtually impossible to put the genie of violence back in the bottle again. It creates its forms of power, and out of the subjective intentionalities of those who participate in it. This power, collectivizes individual experiences, constituting interpretative codes with their own social texts which participants read differently from outsiders.

Which suggests an even more general argument. That political violence is a particular way of generating interior meanings which form their own discourses constitutive of discourse communities which depend on violence for their existence. ${ }^{20}$

\section{Pedigree Marxism}

We will use the Yan'an case to further illustrate how these categories can be used. However, before doing so we want to show how it fits 
within a Marxist and radical revisionist tradition which provided it with a usable pedigree that went from Marx to Lenin, to Stalin to Mao. In this sense it is necessary to discuss some of the implications of an original Marxism before showing Mao's own expropriation of them.

Marxism is, in this sense an originating inversionary discourse with putative descendants. It provides the original political language for a theory which creates its own myths, its own codes and which by endowing historical events with symbolic significance transforms them into a social text.

As suggested, inversionary discourse contains an upending or transformational goal aimed at rectifying perceived structural injustices. Marxism embodies an inversionary discourse incorporating both history and logic, and a disjunctive transformational moral moment. In Marxism the "contradiction" is between an increasingly functionally marginal bourgeoisie holding on to state power in the face of a politically marginalized but otherwise functionally significant proletariat, kept at bay by the hegemonic power of the state. This hegemony is embodied in the dominant discourse of capitalism and the police power which is its surrogate. So an inversionary discourse must be created which "reveals" this contradiction. Realizing both the truth of the discourse and the consequences of the contradiction provides for an exchange of meaning along side of the inevitable explosion of the developmental contradiction itself.

That is the proletariat, as the value creating class, which contributes virtually everything to the social product confronts an increasingly functionally superfluous class, the bourgeoisie. The latter expropriates all but the subsistence value of that social product. Hence the necessity for a disjunctive and transformational break.

The discourse "works" both as an evolutionary developmental narrative, which one might call the myth of historical materialism, and a text in which there is embodied the logic of transcendent outcomes the two combining to form a highly integrated inversionary discourse in which myth and logic, in the form of narrative and text, constitute both "evidence" and a logic of necessity. ${ }^{21}$

The myth centers around the struggles of an emergent, value producing proletariat. The logic shows why and how it becomes more and more functionally significant and both so central to the entire system of productive capitalism and so threatening to its relations 
that it needs to be politically marginalized, which in turn is the central activity of the state. Capitalism as a dominant discourse then represents a false consciousness and the fetish of commodities. The moral moment of revolutionary change is when mature or late capitalism "splits asunder". The result: a new condition of possibilities afforded through the socialization of the means of production and the universalization of the proletariat from a functional class to a functioning society. ${ }^{22}$ At this point ends become individualized rather than collective. The need for a state largely disappears and with it any discourse of domination as well.

Of course if "one capitalist kills many" one Marxism spawns many others, revisionary rather than inversionary in form. One could include in this the moralistic anarchism which opposed Marxist political formulations from the start, more moderating alternatives vis a vis the revolutionary denouement, (as with Kautsky or Bernstein) or still others elevating revolutionary struggle as a thing in itself as in Lenin and Mao Zedong, and for whom the purgative aspects of violence were essential to the transformational project. What Lenin and Mao did was to shift the revolutionary venue to countries without large proletarian classes, changing the logic of necessity to a necessary praxis, thereby providing the communist party with the special role as prime agent of historical change, i.e. to produce the "inevitable" consequences of a history which had not yet taken place.

\section{Yan'an as a Revolutionary Simulacrum}

We will now illustrate how this Marxist pedigree was misinterpreted and reinterpreted by Mao on his own terms and partly by default as well as design. Yan'an was, as has been suggested, the classic case of a revolutionary and inversionary discourse community. In its time it became a simulacrum, revolutionary in objects, disjunctive in strategy, and morally displacing in ambition. I will also regard Mao as a figure something like Foucault's Great Interpreter, i.e. a cosmocratic purveyor of an applied logic constructed an inversionary discourse of out of the themes of loss, lost individual peasant patrimonies, loss of the national patrimony, how chaos came to rule as a result, and how both defined the redeeming revolutionary project. I will then show how, once it became dominant, the discourse imposed its ex- 
clusionary boundaries to create a counter-simulacrum in Tiananmen Square in the spring of 1989.

The starting point for Mao's inversionary discourse was a double marginalization - peasants as an insurrectionary rather than a revolutionary class and China as a state, both the consequence of interventionist imperialism. In Mao's treatment the peasantry were no simple substitute for a proletariat as in classic or even Soviet Marxism but, as in anarchism, a class of the dispossessed, a class of lumpens, victims of both imperialism and compradore capitalism. Peasants then were representative of the authentic Chinese as "Negativized Others". ${ }^{23}$ They represented the starting point for a train of events, a sequence, a history, a narration from which it was possible to derive a logic of necessity which gradually hardened into the corpus of Mao Zedong Thought.

Mao, part Odysseus, part putative Socrates, provided both a mythic narration in the form of story telling, along with texts containing a projective logic. He attributed to imperialism China's shame, loss, the "poisoning" of the body politic through the diseases of corruption and the afflictions of externally imposed opium, and touched the private bitterness, the immolations and agonies so many experienced with a logic of transformation, redeeming the diseased human body and transforming it into the Übermensch - the "good communist". ${ }^{24} \mathrm{He}$ created in Yan'an a discourse community as a revolutionary simulacrum.

This suggests that a good deal more was going on in Yan'an that it appeared. It was, of course, a military redoubt. It was also a place where the Chinese communists retreated during the Long March, to lick their wounds (with sheer survival as their immediate object). It was there too that they were able to turn disaster into instruction, and instruction into eventual victory. There a rather diverse band became totally reorganized into a disciplined force. Followers of other communist commanders and military leaders were reeducated, and pried loose from their organizations, to be sent elsewhere for service.

All this under conditions which varied from harsh to catastrophic. In December 1937, in Nanjing alone, 300,000 Chinese were killed and thousands of women raped, and assaulted. In 1938, two years after the Border Region was established, the Japanese occupied Beijing, Tianjin, and shortly thereafter, Shanghai and Nanjing, consolidating 
their control over the cities of northeast China. It was a period in which the war was almost lost. By 1940, Yan'an faced virtual starvation, threatened not only by the Japanese but the superior forces of the GMD. ${ }^{25}$

To survive at all meant that a special political chemistry was at work in Yan'an. Partly the very destructiveness of the Japanese campaign increased the determination of young Chinese "joining the revolution" and passing through the dangerous boundaries imposed by Japanese and Nationalist armies. But once inside, those who joined went through an experience closer to a religious conversion than anything else.

Mao was at once story teller and interpreter of logical truth. In the first he uses the raw materials of Chinese history for his troping of facts. In the second, he draws on the historical pedigree of Marxism, through Leninism, and Stalinism, both to validate his own position, and to distinguish his contributions to Marxist theory from theirs. One ought not forget, as well, that in fact the political situation was not only one of revolution and war, but the GMD was the surrogate of the United States and, in this context, the CCP was the surrogate of the U.S.S.R. in the struggle between these two countries, and in a growing atmosphere of capitalist - communist political paranoia. Hence, if Yan'an was far from the centers of China, geographically marginalized, and at first too trivial and primitive to be taken seriously, it became a lightening rod for conflicts of world significance.

Secondly, one needs to remember too, that Yan'an represents an internecine struggle within the CCP itself, a product of factionalism in which a "republic of clandestinity" with its own murders, betrayals, tortures, went on between communists. In Yan'an this kind of killing stopped. But it was replaced by Rectification, which from 1942 on became the point at which Mao's narratives and texts became the central focus of life in Yan'an itself.

So much so that in Yan'an Mao's version of Marxism virtually became a form of revolutionary Platonism. Improvised military strategies, not all of them successful, but drawn from concrete events, victories and defeats, became elevated to doctrinal writs. These in turn were given the force of special insight, breaking the pattern of conventional beliefs but even more, elevating within Marxism, a local and homegrown variety which, provincial in origin became uni- 
versalized, indeed seeking to become dominant within the discourse of Marxism itself.

Beginning as a military redoubt, Yan'an became an instructional community. ${ }^{26}$ Coming to power during the Long March, Mao, who was formerly more or less "exiled" from the party center now became the main actor in the party itself. His role as a military leader, an Odysseus figure wandering in the wilderness in seeking to redeem the lost patrimonies, changed into that of party chieftain and more, a Socratic figure, a rustic theoretician with insight into higher truths not visible to the naked eye.

Three factors contributed to Mao's rise to power within the party. First he had to outwit those who threatened him in intellectual, ideological, administrative and military terms, and eliminate their support. In this respect he was a shrewd and supple adversary whose personal style easily led such opponents as Wang Ming, Zhang Guotao, and others who had major support either from within or outside the party to underestimate him. Second he was a remarkably good story teller who translated the history of China's "fall" in a context of double marginalization, the loss by the peasant of his patrimony to landlords, and the loss of the national patrimony into the imperialism, a process beginning with the Opium Wars and leading to a general condition of political chaos after the downfall of the Qing Dynasty.

Contained within the long story are echoes of past struggles within present ones, as the Taiping rebellion. Its ecclesiastic language was now replaced in a reenactment of peasant rebellion and war. It is in the long story too that Mao developed his theory of a radicalized peasantry as an insurrectionary class.

Inside the long story is an intermediate one. This involves the double conflict, war against the Japanese invader and revolution against the Guomindang. The two become intertwined in a continuously unfolding and shifting set of principles and strategies, an intricate intellectual ballet. At stake is not only which political entity, the CCP or the Guomindang, will succeed in claiming Sun Yat Sen's political inheritance. It is also over which side will represent an authentic Chinese political solution to the prevailing chaos, and also win the war against Japan. The moral issues of power are thus contained in a context of political chaos and war. The intermediate story "orders" this chaos in a context in which the Chinese Communist 
Party succeeds against the overwhelming military power of its enemies, proving the moral superiority of its mission, the authenticity of its ideology, and the power that symbolic capital can generate against military and economic power. Not only was the GMD discredited in the process but the CCP and its Marxism becomes authentically "nationalized".

Before this could happen, however, Mao and his cohorts had themselves to become dominant in the party. Hence the short story is one of struggle with opponents inside the party. Here the vicissitudes which the party had been subject to were turned upside-down. Defeats became testimonials to the failed logic of Mao's revolutionary opponents and victories became evidence of Mao's superior insight and vision. As one goes from the intermediate to the short story, there are more and more "miracles" of survival, distinctive points for the reinterpretation of experience, the Battle of Jinggang Mountains, the Nanchang Uprising, Autumn Harvest Uprising, not to speak of the virtually biblical proportions of the Long March itself, whereby the transition from the intermediate to the short story is made. ${ }^{27}$ In the year of wandering, the rapidly dwindling band of survivors who came to rest in Yan'an, far from the centers of China, holed up in caves and there recreated the lost revolutionary simulacrum under the most primitive conditions. The intermediate story recounts events like so many stations of the cross and like a biblical tale, arranges episodes of suffering, danger and death, in terms of sacrifice, martyrdom and survival. Guomindang China is, in this story, apostate in its relations with Japan, a party of sin to be overcome in order that China be rescued from the enemy and redeemed from itself. It is the long story which defines the project of redeeming the lost patrimonies and purification from a defiled and polluted state (with opium in its bloodstream) and overcoming a society totally corrupt. Each story is complete with events as metaphors of loss and redemption.

And each is an occasion for logical instruction. The story of peasant loss and national patrimonies expropriated by imperialism is a metonymy for primitive accumulation in compradore capitalism, rural squeeze and the plunder of China's resources. The intermediate story is the question of the stage of the struggle and how to convert a national and bourgeois democratic revolution into a communist one. The third is the shift from a theory of proletarian revolution to a 
peasant revolution in which the party becomes elevated above the class and the instrument of the disjunctive break in the absence of a large and functional proletariat.

In the three stories Mao triumphs within the CCP as the agent of the larger history. As the stories focus on Yan'an, Mao becomes the agent of his own story telling, his image becoming larger and larger in the optic of the stories themselves. He moves from a military periphery to the party center and displaces those previously at the center. He transforms himself from an Odysseus wandering on the Long March and seeking to recover the lost patrimony to a Socratic agent with a superior truth waiting to be liberated by him.

The parallelism between story telling and theory construction, myth and logic, narrative and text was carefully orchestrated and choreographed. Yan'an became an instructional community as the survivors of the Long March were joined by thousands of young Chinese who crossed through Japanese lines, it was systematized as a corpus. Living in caves revolutionaries became students. From 1943 on their syllabi required detailed analysis and intensive discussion of 22 texts, some Marxist-Leninist, some Stalinist, some Maoist. Each of the texts recapitulated elements of the long, intermediate, and short stories as "evidence" for the truth claims and superior strategies of Mao and his followers.

Stories and theories worked like nesting boxes, each fitting into the other. Time became foreshortened as events moved into the present in a context of decisive confrontations, war and revolution. Symbolic condensation, foreshortening of history, converted past into the present in which Mao become the center of his own stories. In turn, time became space, i.e. Yan'an which now took on the properties of a revolutionary simulacrum poised half way between the revolutionary struggle up to the present, and the means of transforming the future.

For this latter projective goal to be realized everyone had to know both the language and the logic embodied in the texts, down to virtually identical ways of expressing them. Countless meetings, pamphlets, campaigns, drenched concrete experience in words and documents. Each individual experience was conveyed to the group. Individual stories were fitted into these three collective ones. In turn each individual translated his or her experiences into the theoretical language prescribed. Education became a means of overcoming ig- 
norance, illiteracy, ill formed and previous ideas, so that knowledge as an individual overcoming project was subsumed under the collective one. Individuals merged their personal experience in the collective one, and drew down a superior form of insight and knowledge, a form of empowerment. In Yan'an the party became the surrogate for a universalizing theory with transcendent ends.

I emphasize events as story telling and theory construction as crucial ingredients in the constructed mytho-logics of the party. But as a process of symbolic condensation in which Yan'an becomes the revolutionary fulcrum, an Archimedes point, it suggests the significance of symbolic capital in generating organizational loyalties, discipline, insight, and obligation. Indeed, this was the particular accomplishment of the Rectification Campaign which beginning in late 1942 transformed a somewhat more tolerant political community into a highly disciplined one. Rectification permanently marked both the party and its adherents. It employed strategies of confession and purification to root out remnants of the conventional doxa. It was facilitated in Yan'an by the arrangement and organization of the community in small living and study groups, organized around instructional centers, universities, military academies, arts and literature institutes. Its messages were extended through the use of theater, arts, writings. Everyone in Yan'an became involved in the creation and dispersion of the discourse according to approved rules and by a process of exegetical bonding which seemed to offer new insights into the self as well as society. So much so that individual overcoming projects became intertwined with the larger and collective ones in an atmosphere of purity and danger. Before rectification Yan'an appeared to such foreigners as Edgar Snow and Agnes Smedley as a radical version of the New Jerusalem with all the power that conviction and logic can endow. Afterwards, although not for Snow, it took on more confining characteristics. ${ }^{28}$

What were the longer term effects of such story telling, mythmaking, narrative retrievals, and logic, theory, dialectical modes of explanation and projection? They produced a remarkable degree of symbolic capital in compensation for the lack of economic and other forms. They combined within the corpus of Mao Zedong Thought as an inversionary discourse based on a theory of marginalization of the peasantry and a politics of repossession and transformation. They produced an interior language so that the participants became 
a people of their own texts, a shared sense of empowerment, a validating truth, and a remarkable level of commitment and integrity.

Once the CCP came to power in China, Yan'an became the legitimizing myth of the revolution. The stories became ritualized, set pieces of a history which faded into China's infinite past. The revolutionary disjunction which was to become a process of irreversible change to a higher form of social existence based on the superior knowledge of Mao's formulation, became the basis for a new form of bureaucratization. The discourse became hegemonic. So much so that even Mao attempted to explode it from within. What he must have recognized is the curious impotence that results from the transition of an inversionary discourse into a dominant one. It does not generalize freedom in the resolution of the social problem but bureaucratizes the social problem and becomes hegemonic. In the end not only did this produce widespread dissatisfaction and the chaos of the Cultural Revolution. It led to the counter simulacrum which was tragically destroyed in Tiananmen Square on the morning of June 4, 1989.

What we can see in Yan'an is how discourse, constituted a form of moral exchange involving symbolically loaded signs and signifiers interior to the Yan'anites, setting that community apart not only from the rest of Chinese society but segregating them from opposing factions within the party itself. There were many other base areas but none assumed significance in these terms. Moreover, such "interiority", counterpoised against "exteriorization", distanced Yan'an from the rest of society morally and in terms of political commitment. It defined the positive pole to society's negative pole with the task of absorbing the latter into the former, i.e. the generalization of the CCP into society as a whole and by the use of state power. The Yan'anites as an surrogate instrument for a moral discourse now sought to permeate and endow with special meaning virtually every act of society from the most ordinary to the most politically esoteric. The result was to use the corpus of Mao Zedong and the texts compressed into the parables of the Little Red Book as a method of exegetical bonding, symbolic intensification and condensation.

Embedded, too, in nature of the struggle was the premise and promise not only of a political transcendence after the revolutionary disjunctive struggle, but a developmental solution. This solution in- 
volved the generation of massive amounts of symbolic capital into economic capital and to recapitulate on a state level what was the accomplishment of Yan'an. Moreover, the objective was to increase the importance of symbolic capital as a form of mutualism which eradicated self interest, to prevent a return to what Elster has called methodological individualism. Hence the continuous alternation strategies, loosening up and liberalizing, cracking down, left becoming right, right becoming left, and with each turn of the screw, the identification by the state of enemies to be eliminated, and, of course, victims, reaching a crescendo during the Cultural Revolution itself. The party as the agent delegated the responsibility of extending collective individualism from Yan'an to the state itself, became, at the same time, subject to the return to interests and methodological individualism inherent in economic capital. In this fashion symbolic capital, instead of generating economic capital, became the false consciousness of the Maoist party-state instead of as intended, the consolidation point of irreversable change.

Neither Mao nor his associates were prepared for the bureaucratization of both party and state and within it the return to patterns of political and social life deeply embedded in Chinese society now emerging within the party and the bureaucracy. Hence, Mao found himself supporting his own version of permanent revolution. But here his text left off. There was no projected logic of prescribed ends. Yan'an became the ritualized myth of a revolution increasingly discredited by the efforts to prop it up and for the old Yan'anites, a form of nostalgia for what might have been. In the name of a Chinese Spartanism and self discipline it has resulted in guanxi socialism a politics of localized interests in which party officials are only one particular category of entrepreneurs among many.

\section{The Cosmocratic Impulse}

Fashions in violence have changed just as types of political analysis have. Revolutionary ideological movements are out while more ethnically or religiously inspired are in. Nevertheless, I believe that the Yan'an case continues to work very well to illustrate both in general and particular ways how inversionary discourse theory works. Mao's putative Marxism, ostensibly structural, i.e. as system of developmental and historical transformation applied to the historical 
evolution of China, in fact constitutes a mixture of interpretive strategies which make use of "objectivized" categories to disguise the element of contingency, recasting it as historical mythology and programmatic utopianism. Indeed, looking back on the Yan'an period, we can see clearly how presumed historical truths were embodied in narratives which, mixing fact with fantasy, realized themselves in the form of myths - myths constituting what might be called the "imaginary real". From such an imaginary real Mao constructed a dialectical and millennial logic which served in effect as a self-fulfilling prophecy.

We have seen how in Yan'an and under conditions of civil war and invasion, a projective millennialism was formed out of a particular reading of history. Selected events, made promontory by means of retrieving narratives provided the materials for a projective millennialism. With them, and indeed, embodied in the narrative were texts which, in an ostensible context of education, generated a tutelary and mobilizing community with its own theory and language. So much so that those who joined the revolution became not members but Yan'anites - a chosen people, a people of the texts if not the book.

As to the discourse itself, it exhibited a particular recounting of a more general set of properties including a definition of marginalization in terms of loss, dispersion, depatrimonialization at the hands of enemies and traducers, imperialists, compradores, etc. In the actual narrativizing of history what was cultivated was a retrospective anger and the cultivation of a restorative yearning. These were cast in the form of a peasantry surrogate for historical process and a commitment to specified higher moral goals, logical and revelatory,deductively formed into binding obligations on the basis of the shared insight of dialectical understanding. These elements can be applied to other discourse communities, ethnic or linguistic, or racial or religious, in which actions of violence form into social texts from which can be derived certain categorical political imperatives. Required for this is a cosmocratic political leader able to translate these ingredients into the immediate context of lived experiences.

But whose discourse was it? The quick answer in Yan'an is also a general answer for inversionary discourse movements generally. It was the discourse of the Great Interpreter, one which he or she did not appear to have fashioned by his or her self. One might say that 
discourse communities are invariably a realization of a certain symbolic and linguistic choreograhy designed by the cosmocrat leader and his or her immediate band of acolytes. Cosmocrats give Voice, but in a fashion which implies that they are vehicles through which pass higher truths. They do not invent. They interpret what is already invented, in the process adding something of their own including the freshness of their own and the common experience. Cosmocrats are the catalytic converters of discourse. They possess special qualities not least of which is a certain impersonal personalism or abstract personalism which makes them both superhuman and human simultaneously.

They may use their own life histories to endow themselves with a convincing commonality, while proving their exceptionality by maintaining distance. They are one with others, and apart. Which gives them the quality of an insider-outsider. They also acquire morally attractive roles.

Mao Zedong is a case in point. As already suggested, he was first an Odysseus figure, exiled twice, once from family and personal friends to become a wanderer experiencing homelessness and vulnerablity, later within the party, where he was distanced from the center and turned to his home province for sustenance and recuperation. In both cases he came to stand for the lost patrimony. And like Odysseus, through suffering and danger he gained the shrewdness and wisdom to recapture it. The exile's return is the triumph of the collective will.

And, disguised by a style of personal reticence the appearance of natural modesty, was a profoundly ambitious Socratic pretension which drove him to become the self appointed and party anointed agent of history. In both roles he could give voice to truths and like Lenin, project a future complete with rules for more virtuous living.

In these contexts Mao manipulated violence. He did not simply react to provocation. He orchestrated it, even choreographed it. $\mathrm{He}$ found work for all manner of insurrectionaries and terrorists. $\mathrm{He}$ played with his intellectuals treating them now as high priests, then as shamans, and finally converted them into political fetishists of his revolutionary enterprise. ${ }^{29}$ Whatever his politics was, it was always a surrogate for something else.

Those who, in opposing him, failed to make these connections, were quickly penalized. No one in Mao's revolution was allowed the 
luxury of innocence. One was for or against and if for, was expected to be willing to sacrifice. Discipline, will, martyrdom, yes. Mediation no. ${ }^{30}$ Despite the appearances of the United Front.

To be an insider meant learning the codes. Once learned these enabled them to interpret both their own immediate circumstances, and, antagonistically those of their opponents. In this sense what went on in the Chinese revolution were neither "discursive exchanges" between rival ideologies, nor occasions for discursive obliteration. If, as already suggested, time was foreshortened leading to the present, and converted into space - the terrain of Yan'an becoming a revolutionary simulacrum, so its "sovereignty" was a moral one, challenging the larger authority of the Nationalists. ${ }^{31}$ In the praxis that went with the theory killers regarded themselves as healers - healers killed. Postponed outcomes encouraged struggle as a way of life. Significant events piled up and accumulated, and were cosmocratically transformed into revolutionary metaphors. Death was estheticized martyrdom. Within the space of Yan'an, surrounded by its mountains and loess hills, there was theater, drama, music, spectacle, continuous study, interminable meetings, reinforced by insignia, weapons, and the totems and taboos of an interior order. ${ }^{32}$ So constituted, Yan'an as a discourse community was centered between boundaries of purity and danger, to provide a sacerdotal efficacy. ${ }^{33}$ Here memory became desire, retrieval and projection pathos. One might say that in these terms Yan'an became a Tantric circle with Mao at the center. ${ }^{34}$

Once the millennialism had become ritualized, the method cannibalized, the party bureaucratized and the radical state even more rigid than its predecessor, it became one of the several objects of the Cultural Revolution to restore and re-generate the Yan'an discourse, to prop up a rapidly failing moral momentum, and restore the Tantric circle with Mao at the center. The party, suspicious of disjunctive radical solutions and even more so the logic accompanying them saw Mao as part of the problem rather than the solution. What remained of the Yan'an of the moral moment of 1936-1943 became the cultural property of its survivors, ${ }^{35}$ the vanishing point of a revolutionary legend and the authorizing myth of the Maoist state. ${ }^{36}$

The Maoism that formed in that original "simulacrum" Yan'an realized itself in a totalizing and "irreversible" revolutionary community. Its discourse produced symbolic capital in the absence of the 
economic kind. It sought to realize itself as a midpoint in history and a midwife of national revolution. What it established, and that only temporarily, was a "tribe" in which the discourse conferred a surrogate kinship on all those within it linked to the totemic figure of Mao.

So powerful was this radical kinship that it pervaded the 19 other base areas, generating a field of force beyond its boundaries. It sponsored imaginative leaps within the so-called framework of MarxismLeninism and theoretical twists which, pragmatic and dialectical, defined more tightly the theoretical space in which Mao occupied the center. Unlike Lenin, for whom the proletariat represented an inversionary or revolutionary class with radical brains, Mao had to work with an essentially insurrectionary peasantry of radical chains. So defined this gave the party its unique role, to supply the radical brains in the absence of a large proletariat.

But brains alone could only be important if it also became incumbent on all the insiders to learn the "tribal language". By learning the lessons of revolutionary "texts" new insights would be instilled. The "elect" would thus gain privileged insight into the dynamics of political and social life, leading to a "higher" understanding of causes and likely effects, from which superior strategies for revolutionary action against the Guomindang and the pursuit of the war against the Japanese invader were derived.

In this sense by means of a process of exegetical bonding, and in a context of inner party struggles, civil war, and anti-imperialism, the discourse was totally inversionary, casting out alternatives, liberalistic, the fascist Methodism of Chiang Kai-shek, as well as more orthodox forms of communist doctrine. This preferred inversionary discourse was celebrated and validated in every aspect of organized life, from sports, to ballet, to opera, to poetry, etc.

Each incorporated the same themes, loss, displacement, and political yearning, peasants marginalized through the loss of their patrimonies, the state through loss of the national patrimony to the imperialists. Each converted the peasants from "invisibility" to extreme visibility, each aspect of dress, work, action portrayed with descriptive realism and ritualized scenarios. Making peasants visible in this sense ratified and sinified the revolution.

The Long March was the high road to Yan'an. The road away from it was the successful transition from radical tribalism to state; power. 
The transition negated virtually all the original objectives. From radical tribe to hegemonic state is virtually a textbook version of Foucault's paradox. And so it with the conclusion both came too - a variant of the doctrine of permanent revolution. ${ }^{37}$

Did Mao himself realize that no final resolution of negative contradictions is possible and no resolving theory of his would work to the general good? More interesting - did he know it at the start? For it is not necessary that the high priests of religion believe in it, but only its adherents. Did he realize the nature of the movement he had promulgated and that only by maintaining revolutionary momentum could he keep the discourse alive, and only by keeping the discourse alive could he maintain revolutionary momentum?

There are no clear answers to such questions. But it is clear that Mao's view of politics was always perverse. And if we find in it evidence for some of the ingredients we call Foucault's paradox, the ultimate paradox is that its only solution is that a violence feeds on itself above and beyond any normal considerations of interest or rationality. Indeed, it helps explain why for some movements ending violence is the end of the world while violent struggle is the beginning of it.

For Mao self generated violence became the revolutionary necessity. There was neither defeat, victory or mediation. The revolution which he made, and in the end came to oppose had succeeded in all its ostensible objects. It rid itself of invading and imperial powers. It freed itself from a tyrannical regime whose long standing injustices it rectified. In short its accomplishments became the instruments of its demise. ${ }^{38}$

In Yan'an it is possible to see how the immediate past became a plunderable resource for the CCP affording the materials for a narrative out of which an inversionary discourse was formed and with redeeming and transformational objects. It is an interesting case because, as with Plato's Republic, it appeared to reveal higher truths realized in superior strategies within a field of civil as well as military force. Simultaneously there was another struggle within the $\mathrm{CCP}$ over which brand of logocentric Marxism would be dominant within the movement and prevail in the party.

And what this somewhat rambling excursion also suggests is that the original Marxian project, a resolution of contradictions, a politics of disjunctive and transformational solutions failed entirely in 
David E. Apter

China, as it did in the U.S.S.R., illustrating the general truth of the Foucaultian paradox.

Yet this does not mean it had no consequence. Its consequence was in the moral moment itself. For each such moment intensifies pathos, and with it a yearning for solutions even though they will not work. Indeed, it is the attempt to make them work which causes revolutionaries to commit new crimes. As a result, in what began as a mobilization space, a revolutionary simulacrum, within which story telling and logical explanation changed the meaning of acts and intentions within a recoded system of signs, tropes and other forms of interior signaling, a turning point was reached when all these became formulaic. It might be that formulaic coding is a good basis for durable communicative networks and communicative acts. The irony of Yan'an is that as its moral moment ended and its formulaic period began, it came closest to the form, although not the spirit, of Habermas' ideal speech situation. ${ }^{39}$

\section{Foucault's Paradox and Permanent Revolution}

No doubt Mao himself saw it coming. ${ }^{40}$ The problem was how to salvage the overcoming project from the disillusionment of the failed solution. It is at this point that the revolutionary project shifts to the explosion of the superstructures and the idea of a continuing revolution which if it never succeeds on its own terms is essential to political life. It is in this context that like Mao, Foucault comes to represent the general disillusion with politically liberating solutions leaving only violence itself as the perpetually liberating project. Mao turned it against the party and the state. Foucault turned it against himself.

If every dominant discourse is intrinsically hegemonic no matter how liberating its intents, so only a continuous anti-hegemonic struggle constitutes a valid politics then what is the point? One possibility is that at the end of their lives and in their different ways both Mao and Foucault liberate us from solutions altogether. But in fact neither came to such a conclusion. Each turned to violation - the violation of the body politic which in fact collectivizes what was for Foucault the violation of an individual body. Foucault's paradox is embodied in a dialectic of mutual violation. That is the individual 
body is violated by the social body which sees itself violated by those who it defines outside its proprietary boundaries.

If no movement achieves either its goals or its programs on its own terms and each in the effort to do so reconstitutes the power of the dominant discourse why then favor inversionary discourse and emancipatory project, especially if one's view of politics is disjunctive rather than ameliorating. The answer for Foucault, as it was for Nietzsche, is that dominant discourse in even the best regulated society is repugnant in the violations and wounds it imposes on its victims. Foucault sees the result of democracies for example, not in the form of some Nietzschean prejudice against mediocracy, or the soggy qualities of Christian citizenship, but a terrible anger over the plight of the Victim caught in the trap of the infinitely postponed rectification. So the Victim is a figure in chains. Hence his is a politics of inversionary confrontation but apolitical in regard to more general solutions. ${ }^{41}$

However, one regards Foucault and his proposed non-solutions, he opens up a way of looking at politics which emphasizes the matter of boundaries, exclusions and inclusions, victimization and invisibility, and in terms far beyond the ordinary one of pressing claims and pursuing interests. For him modern states employ the discourse of science as the basis of exclusionary practices, reinforcing with metaphors of pollution, infection, etc. those at the margin, with cordons sanitaire around sequestered populations in the form of prisons, insane asylums, ghettoes, etc. Indeed, insofar as Foucault remains devoted to Nietzsche it is to state the larger principle within the idea of continuous inversion, that it is necessary in order to realize man's humanity in a world in which the great obstacle is "the spirit of modern culture" itself. ${ }^{42}$

Where the latter looks to the Übermensch as a solution, Foucault looks to the Untermensch. His project is to expose the hidden violence in conventional modes of politics. Even the mildest version of the dominant discourse contains negative hegemonic elements. Why? Because those at the outer fringes of the permissible no matter how fortuitous the cause of their situation serve to substantiate the foundational moral code embodied in the dominant discourse. Hence every dominant discourse generates a quota of Victims necessary to its functioning. Their proportion, and the conditions of their 
existence constitute for Foucault the standard for judging the state as a whole.

The Victim, then, only appears to stand in an equivalent position as Hegel's slaves to masters. But there is no conviction that by liberating the slave one also liberates the master. Foucault is more concerned with the Necessary Victim. His Thief, Murderer, the Madman, Homosexual are both violators and violating. The thief violates the sacrosanct rules of property and the discourse which sanctifies it. The murderer violates the presumed sanctity of life itself and destroys its self-regarding innocence. The madman defies rationality and disrupts the necessary connections between the artful intelligence and rules controlling the human capacity to make reasoned choices. The homosexual violates "nature" as a procreational connection of family and as such disorders the ordering properties of kinship. These four categories are of particular interest to Foucault because they represent a fundamental "ordering" of social life for which there are corresponding institutions - and institutions of confinement and sequester. So too, deviancy is defined and any "marginal", i.e. at the fringe of society, inside or outside its permissible boundaries is a potential victim. From the point of view of society and the state such Victims are transgressors and trespassers. By their very existence they dilute the proper functioning of society and violate its rules and codes. ${ }^{43}$

Foucault does not restrict his discussions to historical examples. He turns attention to the "phenomenology" of victimness. For example a murderer has a persona within the general category. Look at that persona from within and the category dissolves. Such dissolution, however, can not be permitted because it would dissolve the boundaries required by the dominant discourse. For in this view the dominant discourse creates the Victim and depends on the Victim. The victim does not create his or her own condition. ${ }^{44}$ Foucault's then is the theory of transgressive liberation. It is like Jean Genet's The Thief's Journal, a revolt by the revolting. ${ }^{45}$ Violation, disgusting practices, discomforting and discomfiting dress and social objects are crucial to effectiveness. Scandal is its enterprise.

Constituting his own version of a Heideggerian synthesis, a consciousness of the meanings of the events within a life space, Foucault turns our attention to the way in which marginality works from within, the sense of the life world of the victim. It is not so surprising 
because this coincides with the elements of his own life as a victim. His theories may be said to be a personal transcendence over his own predicaments, a translation of the consciousness of the personal condition in which he found himself and was then imposed on him. It is a consciousness heightened by suffering, a struggle involving definitions of loss (even to his own name), and recuperation through transmutation, the mortification of the body personal transformed into an inversionary discourse on the body politic, and purposefully subversive in intent.

The post-modern view increasingly favors the Foucaultian paradox. Every dominant discourse represents itself as ordinary common sense, a doxa. Embedded in this common sense are Victims and negative boundaries. Hence the permanent need for inversionary discourse to shatter the prevailing opaqueness, the false transparency of the dominant discourse. Thus by focussing on the discourse of the damned, the segregated from the rest of the society, those inhabiting secret spaces, jails, hideouts, bath houses, who live within boundaries marked off from the rest of society, intrinsic to it but not of it Foucault's Victims keep transforming the center.

Whether Foucault and his ideas "return", or Mao's or those of Marx, many turn out to be less important than the impaction of inversionary discourse through violence on state and society. The implication of Foucault's paradox and the best part of the inversionary discourse it suggests is the refinement in the definition of victimness such that deficiencies in the principles and practices of equity are fine-tuned and exposed. It argues for a continuous struggle against all forms of marginality and social distancing even while recognizing that to resolve one only locates another. Underlying this is an ultimate purpose, to prevent a total "embourgeoisement of the mind". In this sense inversionary discourse and the movements they sponsor, are essential both to the dominant discourse as well as its victims. Otherwise even the best ordered democracy would become little more than a plurality of entrenched mediocratic hierarchies operating through self-reinforcing discursive codes, practices, networks of meaning and social relationships.

The worst feature of inversionary discourse is the dangers it poses to democracy especially when it seeks to throw into contempt its legislative and judicial instruments, above all the vote itself, as little more than snares which ensure that people are made complicit in 
their own illusions. When, in the name of a higher truth, democracy, even in its social democratic mode, is charged with being intrinsically trivializing to the human personality, destructive of the very human potentiality which it claims to enhance, then conflict may turn into more fundamental struggle. Conflict is endemic in the democratic process. More fundamental struggle is not. Where to draw the line is what might be called the perpetual point of danger for democracies. ${ }^{46}$

In this respect there are always a good many would-be versions of Foucault's Great Interpreter, less Nietzschean Übermensch than romantic facsimile. Whether the discourse they employ takes the form of religious revivalism, fundamentalism, or ideological revisionism, there are victims who can serve as raw materials for the narratives and texts, the inversionary discourse out of which symbolic capital can be formed. Which suggests that there is no way to resolve Foucault's paradox. Mao is dead. So is Foucault. But all around us is the evidence of how a good many efforts to exorcise victimness wind up producing victims of their own. As Dreyfus and Rabinow put it, "As long as the interpretive sciences continue to search for a deep truth, that is, to practice a hermeneutics of suspicion, as long as they proceed on the assumption that it is the Great interpreter who has privileged access to meaning, while insisting that the truths they uncover lie outside the sphere of power, these sciences seem fated to contribute to the strategies of power. They claim a privileged externality, but they are actually part of the deployment of power". ${ }^{47}$

David E. Apter is Henry J. Heinz II Professor of Comparative Political and Social Development in the Department of Political Science, Yale University. The present paper is a revised version of a keynote speech delivered at the First Annual Conference of "The State and Society in East Asia" Network, Copenhagen, May 1993

\section{NOTES}

1 Foucault, since he was within a group that was "without", i.e. beyond the acceptable boundaries of civil society even more than state, had an interior view even when he tried to destroy it analytically. He was, in much of his theory, talking about himself. Morally, therefore, one starts out with a sense of the ambiguity of one's role and to some extent therefore, part of the problem rather than the solution. Studying political violence in this sense can never be innocent. 
2 It is also somewhat doubtful that even the most ardent advocates of the inversionary transformation genuinely believed in the wisdom of their ideas except in some metaphorical way. Despite their ablutions and genuflections before their sanctified "others", it was the claim itself which offered exemption from ordinary moral sense (in favor of a revolutionary one) rather than its truth. It is an old theme.

3 See Hannah Arendt, On Revolution (New York: The Viking Press, 1963), p. 54.

4 It is no wonder that to prevent themselves from the social invisibility prescribed by the dominant discourse, including the discourse of "equality", African-American subculture includes violence against the body, pathologies of self-destruction as well as crimes against property and people who represent the dominant discourse, and a semiotics of protest, from dreadlocks to guns, and from ghetto boxes to rap music.

5 In contrast Foucault's inversionary discourse never achieved a moral moment - nor could it. Nor did Marx quite succeed in realizing one in his own lifetime. Indeed, his disappointment was double, the failures of the Paris Communes of 1848 and 1870, (although he managed to make a good deal of those failures for the development of his political ideas). In this sense both the Bolshevik and Chinese revolutions were a post-Marx dedoublement. For both Mao and Lenin realized in their respective revolutionary moral moments, the "redeeming" proletariat or peasantry, the disjunctive break, and a projective historicism.

6 The Gauche Proletarienne in Paris in 1968 and as well the Situationists.
7 What has been called discourse theory draws on a variety of sources, literary as well philosophical, and of course from several of the social sciences. Such theory can be reworked so that it applies to inversionary movements of various types, from revolutionary insurrection and terrorism to extra-institutional protest.

8 A good example is Armed Insurrection, ostensibly published in Switzerland under the false imprimatur of Zurich: Otto Meyer, 1928 as Der bewaffnete Aufstand, and in a later version in French as L'insurrection armee in 1931. A textbook of revolutionary insurrections each case is written by an author with a fictional name under the general authority of the Organizing Secretary of the Comintern (Piatnitsky).

9 There is a sense, of course, in which the approach favored here is as old as thinking about politics. Indeed, ever since Plato the power of discourse, its components and the realization of its consequences has itself been a discourse running throughout political analysis. He was the first to emphasize how discursive practices, religious, ecclesiastical, secular, logical, logocentric in form constitute a system in which words and meanings have performative consequences. Revolutionary Platonism is concerned with how to convert logically derived truths to actions. In this way words intertwine with deeds and even when disordering in intent, they constitute systems of order, organized killing and healing. A revolutionary movement may indeed prepare text books on insurrectionary strategy constructed around the curative or purging effects of violence - violence as a necessary curative prescription. 
10 See Raymond Aron, History and the Dialectic of Violence (New York: Harper and Row, 1975).

11 See Roland Barthes, Elements of Semiology (New York: Hill and Wang, 1964).

12 See Pierre Bourdieu, Outline of $a$ Theory of Practice (Cambridge: Cambridge University Press, 1972). As will become readily apparent the present usage of the term departs from Bourdieu's. It constitutes a fund of collectivized and interpretative to which individuals make contributions and withdrawals rather than non-economic forms of exchange.

13 See Hannah Arendt, On Revolution (New York: Viking Press, 1963). See also Clarence Crane Brinton, The Jacobins (New York: Russell and Russell, Inc., 1961). Brinton's emphasis on the iconography and performance aspects of political violence has been examined further in Mona Ozouf, La fete revolutionnaire, 17891799 (Paris: Gallimard, 1966). These themes can not only be applied to disjunctive revolutionary themes. They can be extended to such movements as the Mau Mau uprising in Kenya in the 1950's which involved ritualized violations of conventional sexual, excretory, and other taboos associated with the body and around which social practices were constructed. Mau Mau, at least those "decentered" and living in the forests under the most primitive hardship conditions lived up to the extreme social marginality (barbarians, monkeys, etc.) that was assigned to them within the dominant colonial discourse as practiced in the white community in Kenya. There are many such movements in which "outrageous" sin serves as a form of bonded liberation and an interesting literature on the subject which includes Sade, Bataille, and Fou- cault. See Denis Hollier ed., The College of Sociology 1937-39 (Minneapolis: The University of Minnesota Press, 1988). See also, John Barrell, The Infection of Thomas De Quincy (New Haven: Yale University Press, 1991), pp. 147-156, and Stephen J. Greenblatt, "Filthy Rites" in Learning to Curse (New York and London: Routledge, 1990), pp. 5979.

14 Or as Aron puts it, from the Bastille to the Kremlin. For an analysis of the problem of Jacobinism, terror and democracy see Francois Furet, Antoine Liniers, and Philippe Raynaud, Terrorisme et democratie (Paris: Fayard, 1985).

15 As used here political violence is situated between random violence, i.e. outbreaks, mobs, which have a more or less random quality and no specific political objects, and war, the highly structured rational pursuit of military conquest by one or several nations over another or others. Political violence falls within these outer limits. Within these limits political violence takes the one or several forms, each with its own organizational dynamics, extrainstitutional protest, insurrectionary insurrection, and terrorism. In all three discourse theory applies.

16 Although there are plenty of residual revolutionaries like Guzman and his cohorts in the Sendero $\mathrm{Lu}^{-}$ minoso in Peru.

$17 \mathrm{~A}$ list of the movements in one country alone, like India, would literally exhaust the alphabet of acronyms.

18 See Patrick Combes, La Litterature et le Mouvement de Mai 68 (Paris: Seghers, 1984). See also Roland Biard, Histoire du Movement Anarchiste 1945-1975 (Paris: Editions Galilee, 1976), and A. Belden Fields, Trotskyism and Maoism. (New York: Praeger, 1988).

19 See Martin Kramer, "The Moral Logic of Hizballah" in Walter Reich, 
ed., Origins of Terrorism (New York: Cambridge University Press, 1990), pp. 131-157. See also David Moss, The Politics of Left-Wing Violence in Italy, 1969-85 (London: Macmillan, 1989), and Stefan Aust, The BaaderMeinhoff Group (London: The Bodley Head, 1987).

20 There is indeed a large body of literature relevant to the examination of the levels and layered meanings of violence, from Marx to Mao, Sade to Bataille, Levi-Strauss and Barthes to Ricoeur, Foucault, Bourdieu and Baudrillard, and from Jacobins to modern Situationists, with occasional nods in the direction of Futurism, Constructivism, Dadaism, Surrealism, and, modes of exploding the ordinariness of daily life, not a little of it pure political theater.

21 Or, to modify Marx's XIth thesis on Feuerbach ("The philosophers have only interpreted the world, in various ways; the point, however, is to change it."), the point is to change the world by reinterpreting it.

22 The functionally significant take full possession of their patrimony to produce a mutualistic civil society with the revolutionary dictatorship of the proletariat as an interim. That is it remains in order to preside over the disappearance of surplus value and to ensure that the entire civil society receives the full proceeds of the value it produces.

23 See Paul Ricoeur, The Symbolism of Evil (Boston: Beacon Press, 1967).

24 In more general terms Mao defined a negative pole to be transcended and the starting point where structural components of an inversionary theory are "activated" in events, where interpretative retrieval and reenactment becomes part of a phenomenology of overcoming through which, through interpretation, people try to transcend their individual predicaments.
25 See Jonathan Spence, The Gate of Heavenly Peace (London: Penguin Books, 1982), pp. 312-313.

26 See David E. Apter and Tony Saich, Revolutionary Discourse in Mao's Republic (Cambridge: Harvard University Press, 1994).

27 The Long March, which occurred after the Fifth Extermination Campaign launched by the GMD against the CCP ended in the loss of the Jiangxi base, the original revolutionary simulacrum contains ingredients which are equivalent in scope to the biblical crossing of the Red Sea and the creation of a New Jerusalem. Involving a year of wandering through many parts of China, as in some Levi-Straussian myth, it included remarkable exploits of heroic proportions, impossible obstacles overcome, the crossing over hostile terrains, the passing through ethnic boundaries snowy mountains and treacherous savannah. It is also during the Long March that Mao comes to power, and in contention with the leaders of the Comintern.

28 See Edgar Snow, Red Star Over China (New York: Vintage Books, 1947).

29 See Michael Taussig, Shamanism, Colonialism, and the Wild Man (Chicago: The University of Chicago Press, 1991).

30 See Frantz Fanon, Les damnes de la terre (Paris: Francois Maspero, 1961).

31 Democracy is perhaps the one system, though difficult to establish, which has the supreme virtue of keeping ends open while prescribing rules and instrumentalities and institutes for converting principles into interests and therefore amenable to negotiation. In this sense exchanges of meaning take place continuously rather than disjunctively, and simultaneously in the public and private spheres with many points of mediation. 
32 For a discussion of the deceits accompanying this process see David E. Apter and Timothy Cheek, "Introduction: The Trial" in Dai Qing, Wang Shiwei and 'Wild Lilies': Rectification and Purges in the Chinese Communist Party, 1942-1944 (Armonk, New York: M. E. Sharpe), published as Chinese Studies in History, Part I, Vol. 26, No. 2 (Winter 1992), pp. 7-21.

33 See Mary Douglas, Natural Symbols (New York: Vintage Books, 1973), p. 27.

34 For a time it influenced such diverse African political leaders as Kwame Nkrumah of Ghana and Julius Nyerere of Tanzania. It reached its discursive heights during the May 1968 outbreaks in France and in its last dying gasp has convulsed Peru in what might be its most tragic-comic case, that of Sendero Luminoso in Peru. But the Maoism which had its greatest theoretical impact was that which evolved within the Chinese Communist Party between the years 1936-1947 in Yan'an, not only because it became a model liberation ideology but because it had behind it what might be called the transformation of symbolic capital into political power, as exemplified in Yan'an as a discourse community.

35 As a radical political entity Yan'an lasted from 1936 to 1947 when it was abandoned to the Guomindang.

36 As was suggested with reference to the Jacobin phase of the French revolution, we distinguish between revolutions which assert as moral objects radically new doctrinal combinations of social, economic, cultural and political factors from those which leave prevailing the social, economic and cultural basically intact, transforming, as it were, the political mode only, as it was the case in the English and
American revolutions (and in the end the French as well).

37 A "project" that ended with Mao's demise.

38 This differs drastically from the situation in democracies. Since rendering inversionary discourse into improving objects is one of the unique achievements of democracy, (with its virtually infinite capacity for cooptation, and its ability to render the heroic into the ordinary and convert devotional principle into the practical - a bargaining situation), it is not surprising that inversionary discourse against dominant democratic forms seeks to discredit the latter in terms of its hypocrisy. That is, an inversionary discourse needs to show that political solutions that would repair flaws in democracy are not only meretricious but that the flaws are built into the logic of democracy itself. That is what distinguishes movements for reform from those favoring inversion.

39 See Jürgen Habermas, The Theory of Communicative Action (Boston: Beacon Press, 1984).

40 See Tang Tsou, The Cultural Revolution and Post-Mao Reforms (Chicago: University of Chicago Press, 1986).

41 Foucault refuses terms like "ideology". He is not concerned with the play of interests or the coalitional character of mediation politics. His concern is with inversionary discourse and the communities in which they are embedded. For him the democratic solution of open ends and representative means, of politics as a moving equilibrium resulting from the intersecting play between political and economic market forces is irrelevant. Nor is he concerned with the politics of programmatic choices, agendas, parties and voting, of accountability and consent, i.e. of democracy 
as a system in itself. All this is part of the modern society that Nietzsche rejected as mediocre, dispiriting, etc.

42 See Bernard Yack, The Longing for Total Revolution (Princeton: Princeton University Press, 1986), p. 356.

43 See Michel Foucault, Discipline and Punish (New York: Vintage Books, 1979; see also The History of Sexuality (New York: Pantheon Books, 1978), Vol. 1.

44 Thus such a condition derives from within the universe of public meaning. Look at the persona, within the conditions of daily life, and a different picture appears. Foucault makes this point in a "a case of parricide in the 19th century", a book entitled I, Pierre Riviere, having slaughtered my mother, my sister, and my brother... The book itself, the confession of the murderer who has indeed committed the crimes, provides one with the murder's view of the events, causes, and the circumstances and events of the crime. Foucault shows the relationship of the text to that of the Dominant Discourses of criminology, psychology as they have evolved in France in the early 19th century and the relation of them as sciences to law and the exercise of the discretionary power of the state. He shows the discrepancy between the structure of the code and the phenomenology of intentionalities and how for the judges these intersect. The logic of the first leads to a verdict of guilty. The second is more ambiguous. As it turned out the actual guilty judgement of guilty with its sentence to death was commuted by the king's pardon whereupon the pardoned murderer committed suicide. Foucault's reason for republishing the dossier is "to rediscover the interaction of those discourses as weapons of at- tack and defense in the relations of power and knowledge". See Michel Foucault, I, Pierre Riviere, having slaughtered my mother, my sister, and my brother... (Lincoln and London: University of Nebraska Press, 1975), p. xi.

45 See Jean Genet, The Thief's Journal (New York: Grove Press, 1964). It also contains the inversionary symbolic attributes described so well in Sidney Greenblatt's "Filthy Rites" in Learning to Curse (New York: Routledge, 1990.

46 See J. L Austin, How To Do things With Words (New York: Oxford University Press, 1971).

47 See Hubert L. Dreyfus and Paul Rabinow, Michel Foucault, Beyond Structuralism and Hermeneutics (Chicago: The University of Chicago Press, 1983), pp. 180-181. 